\title{
DIVERSITY AND SEASONAL DISTRIBUTION OF PLANKTON IN KHASTE LAKE, LEKHNATH, KASKI, NEPAL
}

\author{
Narayan Datta Bastakoti ${ }^{*}$, and Ganesh Timilsina ${ }^{2}$ \\ ${ }^{1}$ Department of Botany, Prithvi Narayan Campus, Tribhuvan University, Pokhara, Nepal \\ ${ }^{2}$ Department of Zoology, Prithvi Narayan Campus, Tribhuvan University, Pokhara, Nepal \\ *For Correspondence: bastakotind@gmail.com
}

\begin{abstract}
Planktons are the important components of aquatic ecosystem. In this study, we assessed the diversity and seasonal distribution of planktons in Khaste Lake, Lekhnath, Kaski.Samples were collected from three stations from April to September using plankton net of mesh size $60 \mu \mathrm{m}$. The collection period included three different seasons: summer, early monsoon and late monsoon. Altogether 35 genera of plankton, 24 belonging to phytoplanktonic group and 11 to zooplankton, were recorded from April to September 2012. The recorded phytoplankton belonged to four classes namely chlorophyceae, bacillariophyceae, xanthophyceae, and cyanophyceae with fourteen, seven, two and one genera respectively, while zooplanktons belonged to three groups namely rotifera, cladocera and copepoda with three, six and two genera respectively. The dominant class in phytoplankton was chlorophyceae with fourteen genera and in zooplankton was cladocera with six genera. Eleven genera of phytoplankton and five genera of zooplankton were recorded throughout the three seasons of the study period. The rich in diversity of phytoplankton shows high level of nutrient status and the lake changing into Eutrophication Lake resulting from the surface run-off water with fertilizers from agricultural lands and sewage from densely populated area of the surrounding.
\end{abstract}

Key words: Diversity, Khaste Lake, Phytoplankton, Season, Zooplankton

\section{INTRODUCTION}

Water, the greatest factor for life, can be divided mainly into two major types based on their salt content, the marine water with high salt content $(3.5 \%)$ and fresh water with low salt content $0.001 \%$ to $0.05 \%$ (Pennak, 1953). There are great varieties of fresh water bodies such as rivers, lakes, streams, reservoirs, village ponds, paddy fields, etc. The National Wetland Policy of Nepal (NWP/N 2003), has defined wetlands as the perennial water bodies originating from underground sources of water or rains. They are marshy lands, riverine flood plains, lakes, ponds, water storage areas and agricultural lands. In Nepal wetlands occupy 743,563 ha. of area, where lakes alone occupy about $0.7 \%$ of it (Majupuria, 1984-85).

Plankton community, the minute organisms that drift or float passively with water current, is a heterogeneous group of tiny microscopic organisms adapted as suspension in the sea and freshwater (Hesnen, 1887). Based on their habitat, plankton from lakes are called limnoplankton (Battish 1992), it includes blue green algae, algae, diatoms, protozoans, larvae and eggs of some aquatic animals. Plankton have immense value as food and can play an important role in disposal of sewage and in the natural purification of polluted water. They are also important in fossil fuel formation. Contrary 
to the usefulness of plankton, sometimes they become serious problems to the aquatic life. Sudden excessive growth of cyanophyceaen algae due to nutrient availability and rise in temperature called "the water bloom", may be the cause of liberation of certain poisonous chemicals that may destroy the aquatic life, they also impart particular colour, foul odour and bitter taste to the drinking water supply (Prescott, 1961). Specific objective of this study was to investigate the diversity and seasonal distribution pattern of plankton in Khaste Lake.

\section{MATERIALS AND METHODS}

\section{Study site}

The selected study area - the Khaste Lake, with an area of 24.8 ha.and average depth of $2 \mathrm{~m}$ is situated in ward no. 4, Kharane Phant, of Lekhnath municipality in the eastern part of Pokhara valley, in Kaski. This lake is surrounded by hills named Baraldanda, Dhunganathar to west and north, Rakhidanda to east and Kharane Phant to its southern part, in other words, the lake is situated at the southern base of these hills. The total area covered by it is 24.8 ha and average depth of water $2 \mathrm{~m}$ with catchment area of 2.8 sqkm (Panta, 2008).Major inlet or feeding source of Khaste Lake is Thulokhola and other few rivulets, while there is a single outlet called Gaduwakhola which arises from its south-eastern end and it is utilized completely for the irrigation purpose.The surface run-off water and sewage effluents from surrounding cultivated lands and densely populated area of uplands find their ultimate ways into this lake. Local community directly depends upon the resources of lake, for their livelihood such as fishing, grazing, as well as they use the water for washing and bathing purpose.

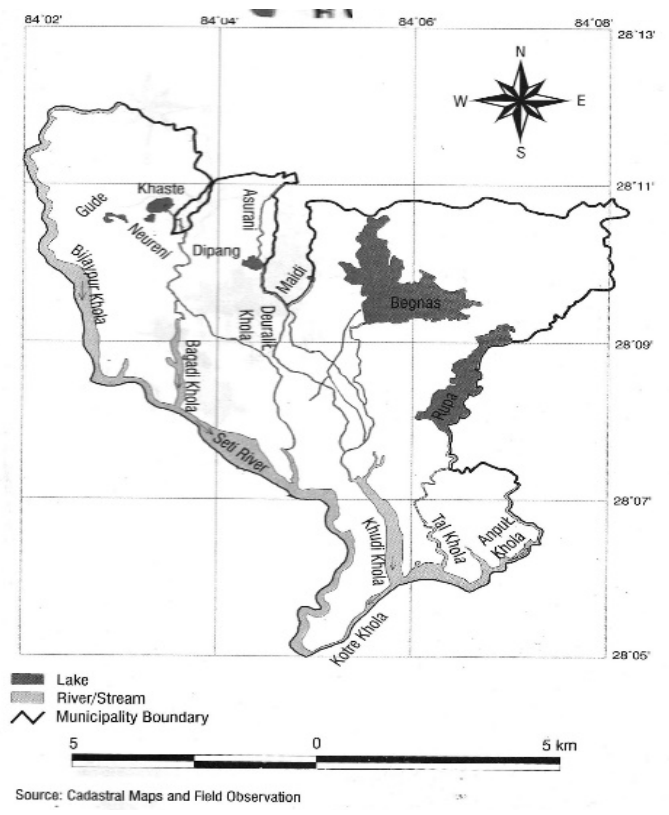

Figure 1: Study site along with other Lakes of Lekhnath area.

\section{Data Collection}

A total of three visits to the study area were made for sampling from April to September 2012, in the interval of two months each. The duration of sampling period was divided into summer (April-May), early monsoon (JuneJuly), and late monsoon (August-September) seasons. Ten liters of surface water was taken from each sampling station and filtered through

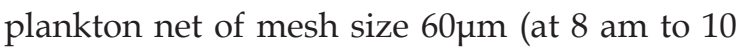
am). The collected samples were preserved in the sampling bottle of $25 \mathrm{ml}$ size in Lugol's iodine solution for phytoplankton and in 5\% formalin for zooplankton, then brought to botany laboratory, Prithvi Narayan Campus, for further investigation. All the samples were studied under compound microscope, then identified up to their generic level with the help of reputed taxonomic literatures of G.W. Prescott (1961), R.W. Pennak (1953) and S.K Battish (1992). Finally, all the identified plankton were tabulated and analyzed in various ways. 


\section{RESULT AND DISCUSSION}

The results of study on planktonic diversity in Khaste Lake are described as followings. The various members of plankton belonging to phytoplankton and zooplankton observed, examined and identified during the study period of 6 months, are shown in tabulated and figurative forms.
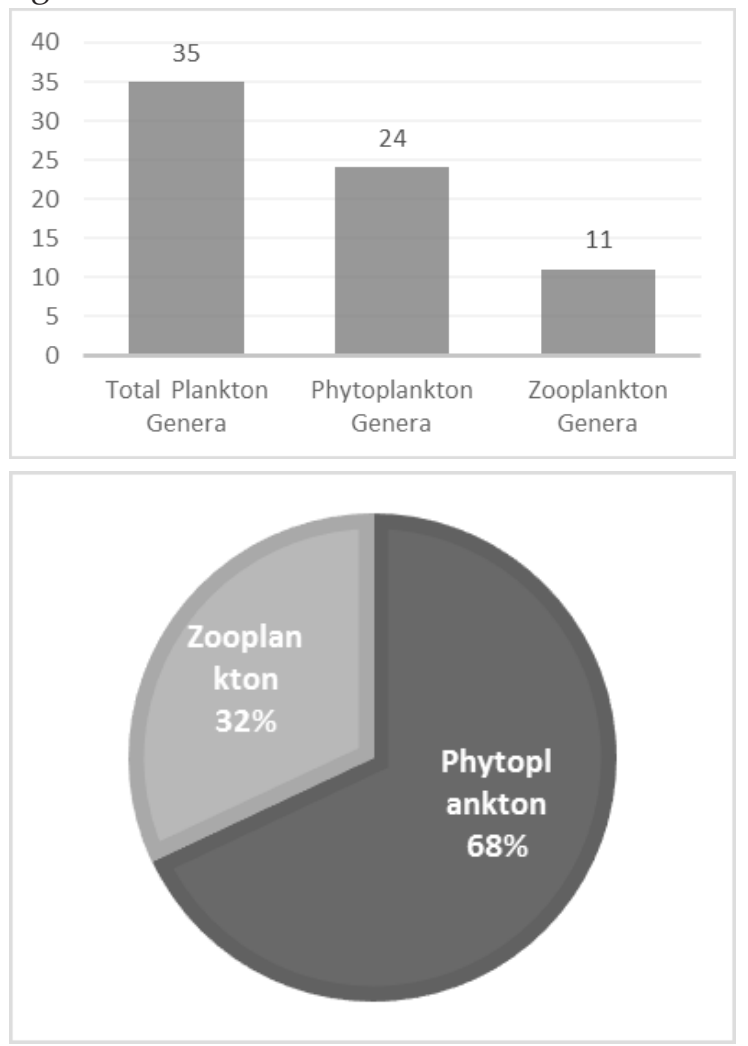

Figure 2: Number and Proportion of Planktonic Genera in Khaste Lake

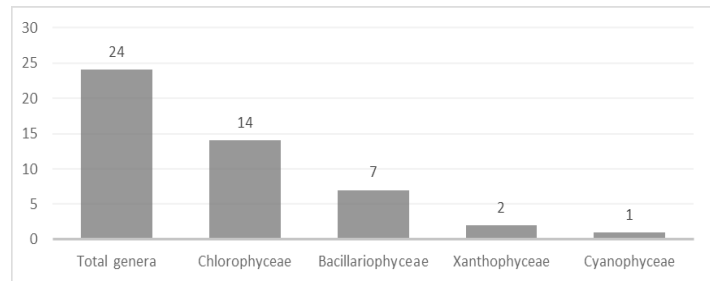

Figure 3: Class-wise Distribution of Phytoplankton Genera in Khaste Lake.
During the study period of 6 months from April to September 2012, in Khaste Lake, altogether 35 genera (Tables 1 and 2) of fresh-water plankton were recorded in which $24(68 \%)$ genera belonging to phytoplankton and 11 (32\%) belonging to zooplankton groups (Fig.2). All these phytoplankton come under 15 families, 10 orders, 4 classes and 3 divisions of algal group (Table 1 and Fig. 3). The class Chlorophyceae and Bacillariophyceae stood higher group consisting of 14 genera and 7 genera respectively but in the Cyanophyceae a single genus Oscillatoria was recorded. Similarly, zooplankton, out of 11 genera recorded so far, Cladocera stood the first group represented by 6 genera, followed by Rotifera with 3 genera and Copepoda by 2 genera. All the zooplankton come under 9 families, 3 orders 2 classes and 2 phyla. (Table 2 and Fig. 4).

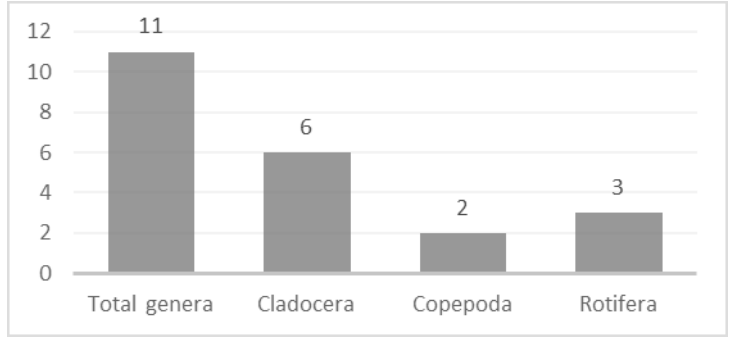

Figure 4: Group-wise distribution of Zooplankton genera in Khaste Lake 
Table 1: Diversity and Seasonal Distribution of Phytoplankton in Khaste Lake, April to September 2012

\begin{tabular}{|c|c|c|c|c|c|c|}
\hline \multirow{2}{*}{$\begin{array}{l}\mathrm{S} \\
\mathrm{N} .\end{array}$} & \multirow[t]{2}{*}{ Genera } & \multirow[t]{2}{*}{ Class } & \multicolumn{3}{|c|}{ Seasonal Distribution } & \multirow[t]{2}{*}{ Remarks } \\
\hline & & & \begin{tabular}{|c} 
Summer \\
(April- \\
May)
\end{tabular} & $\begin{array}{c}\text { Early Monsoon } \\
\text { (June-July) }\end{array}$ & \begin{tabular}{|c|} 
Late \\
Monsoon \\
(Aug.- \\
Sept.)
\end{tabular} & \\
\hline 1. & Ankistrodesmus sp. & Chlorophyceae & + & + & - & S+E.M. \\
\hline 2. & Chlamydomonas sp. & Chlorophyceae & + & - & - & S \\
\hline 3. & Chlorella sp. & Chlorophyceae & + & - & - & $S$ \\
\hline 4. & Closterium sp. & Chlorophyceae & + & + & + & ALL \\
\hline 5. & Cosmarium sp. & Chlorophyceae & + & - & + & S+L.M. \\
\hline 6. & Cyclotella sp. & Bacillariophyceae & + & + & + & ALL \\
\hline 7. & Desmidium sp. & Chlorophyceae & + & + & + & ALL \\
\hline 8. & Fragillaria sp. & Bacillariophyceae & - & + & + & E+L.M \\
\hline 9. & Gonatozygon sp. & Chlorophyceae & + & - & - & $S$ \\
\hline 10. & Krichneriella sp. & Chlorophyceae & + & + & + & ALL \\
\hline 11. & Melosira sp. & Bacillariophyceae & + & + & + & ALL \\
\hline 12. & Navicula sp. & Bacillariophyceae & + & + & + & ALL \\
\hline 13. & Nitzschia sp. & Bacillariophyceae & + & + & + & ALL \\
\hline 14. & Ophiocytium sp. & Xanthophyceae & + & - & - & $S$ \\
\hline 15. & Oscillatoria sp. & Cyanophyceae & + & + & - & S+E.M. \\
\hline 16. & Pediastrum sp. & Chlorophyceae & + & + & + & ALL \\
\hline 17. & Pinnularia sp. & Bacillariophyceae & + & + & + & ALL \\
\hline 18. & Scenedesmus sp. & Chlorophyceae & + & + & + & ALL \\
\hline 19. & Selenastrum sp. & Chlorophyceae & - & + & + & E.M+L.M. \\
\hline 20. & Staurastrum sp. & Chlorophyceae & - & + & + & E.M+L.M. \\
\hline 21. & Synedra sp. & Bacillariophyceae & + & + & + & ALL \\
\hline 22. & Tribonema sp. & Xanthophyceae & + & - & - & S \\
\hline 23. & Ulothrix sp. & Chlorophyceae & + & - & - & S \\
\hline 24. & Vaucheria sp. & Chlorophyceae & - & + & - & E.M. \\
\hline \multicolumn{2}{|c|}{ Occurrence in each season } & & 20 & 17 & 15 & \\
\hline
\end{tabular}

Note: + = Present, $\quad-=$ Absent, $\quad$ S=Summer, $\quad$ E.M.= Early Monsoon, L.M.= $\quad$ Late Monsoon 
Diversity and Seasonal Distribution ...

Table 2: Diversity and Seasonal Distribution of Zooplankton in Khaste Lake April to September 2012

\begin{tabular}{|l|l|l|l|l|l|l|}
\hline \multirow{2}{*}{ S.N. } & Genera & Group & \multicolumn{3}{|c|}{ Seasonal Distribution } & Remarks \\
\cline { 3 - 6 } & & & \multicolumn{1}{|c|}{$\begin{array}{c}\text { Summer } \\
\text { (April-May) } \\
\text { Monsoon } \\
\text { (June-July) }\end{array}$} & $\begin{array}{c}\text { Late } \\
\text { Monsoon } \\
\text { (Aug-Sept.) }\end{array}$ & \\
\hline 1. & Asplanchna sp. & Rotifera & + & + & + & ALL \\
\hline 2. & Bosmina sp. & Cladocera & + & + & + & ALL \\
\hline 3. & Brachionus sp. & Rotifera & - & + & - & E.M. \\
\hline 4. & Ceriodaphnia sp. & Cladocera & + & - & + & S+L.M. \\
\hline 5. & Chydorus sp. & Cladocera & + & - & + & S+L.M. \\
\hline 6. & Cyclops sp. & Copepoda & + & + & + & S+E.M. \\
\hline 7. & Daphnia sp. & Cladocera & + & + & + & ALL \\
\hline 8. & Diaphanosoma sp. & Cladocera & - & - & + & L.M. \\
\hline 9. & Diaptomus sp. & Copepoda & + & + & + & ALL \\
\hline 10. & Keratella sp. & Rotifera & + & + & + & ALL \\
\hline 11. & Moina sp. & Cladocera & - & + & + & E.M.+L.M. \\
\hline- & Nauplius larvae & Copepoda & + & 8 & + & ALL \\
\hline $\begin{array}{l}\text { Occurrence in each } \\
\text { season }\end{array}$ & & & & + & - \\
\hline
\end{tabular}

Note: + = Present, - = Absent, S=Summer, E.M.= Early Monsoon, L.M.= Late Monsoon

On the basis of seasonal distribution, among the phytoplankton community a total of 20, 17 and 15 genera were recorded in summer, earlymonsoon and late monsoon respectively. Out of them, 5 genera Colsterium, Desmidium, Krichneriella, Pediastrum and Scenedesmus from Chlorophyceae, and 6 genera from Bacillariophyceae Cyclotella, Melosira, Navicula, Nitzschia, Pinnularia and Synedra were recorded in all sampling seasons. Four genera from Chlorophyceae namely Chlamydomonas, Chlorella, Gonatozygon, Ulothrix and two genera from xanthophyceae, Ophiocytium and Tribonema, were found occurring only in summer. Vaucheria was recorded in early monsoon only. Ankistrodesmus and Oscillatoria were found in summer and early monsoon only. Cosmarium was recorded in summer and late monsoon, but the Fragillaria, Selenastrum, and Staurastrum were recorded in monsoon only, (Table 1 and Fig. 5). 


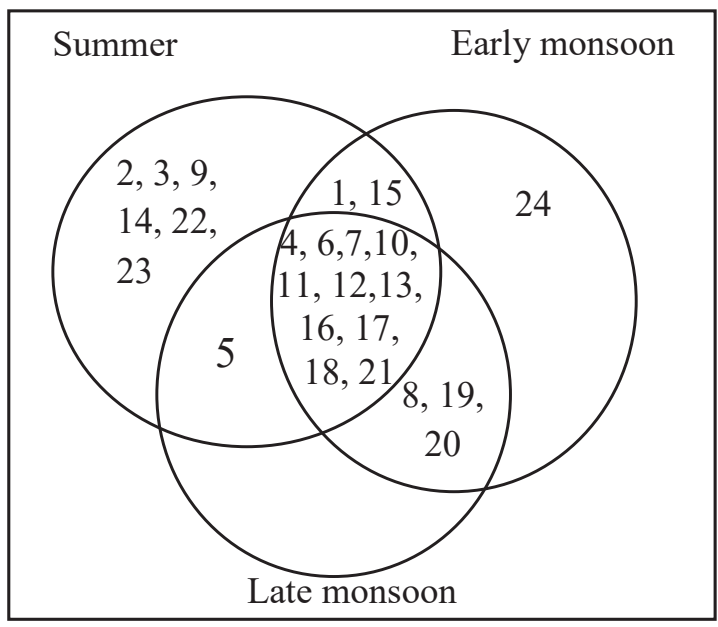

\begin{tabular}{|l|l|l|l|}
\hline C.N. & Phytoplankton & C.N. & Phytoplankton \\
\hline 1. & Ankistrodesmus $s p$. & 13. & Nitzschia $s p$. \\
\hline 2. & Chlamydomonas $s p$. & 14. & Ophiocytium $s p$. \\
\hline 3. & Chlorella $s p$. & 15. & Oscillatoria $s p$. \\
\hline 4. & Closterium $s p$. & 16. & Pediastrum $s p$. \\
\hline 5. & Cosmarium $s p$. & 17. & Pinnularia $s p$. \\
\hline 6. & Cyclotella $s p$. & 18. & Scenedesmus $s p$. \\
\hline 7. & Desmidium $s p$. & 19. & Selenastrum $s p$. \\
\hline 8. & Fragillaria $s p$. & 20. & Staurastrum $s p$. \\
\hline 9. & Gonatozygon $s p$. & 21. & Synedra $s p$. \\
\hline 10. & Krichneriella $s p$. & 22. & Tribonema $s p$. \\
\hline 11. & Melosira $s p$. & 23. & Ulothrix $s p$. \\
\hline 12. & Navicula $s p$. & 24. & Vaucheria $s p$. \\
\hline
\end{tabular}

Figure 5: Seasonal Distribution of Phytoplankton genera in Khaste Lake

Among the zooplankton community, a total of 8,8 and 9 genera were recorded in summer, early monsoon and late monsoon respectively, out of these, Asplanchna, Bosmina, Daphnia, Diaptomus and Keratella werefound in all seasonsof sampling period; whereas Brachionus was noted in early monsoon and Diaphanosoma in late monsoon only. The cladocera members Chydorus and Ceriodaphnia were recorded in summer, not recorded in early monsoon but reappeared in late monsoon. The genus Moina was not observed during the summer, similarly Cyclops was not observed in late monsoon. (Table 2 and Fig. 6)

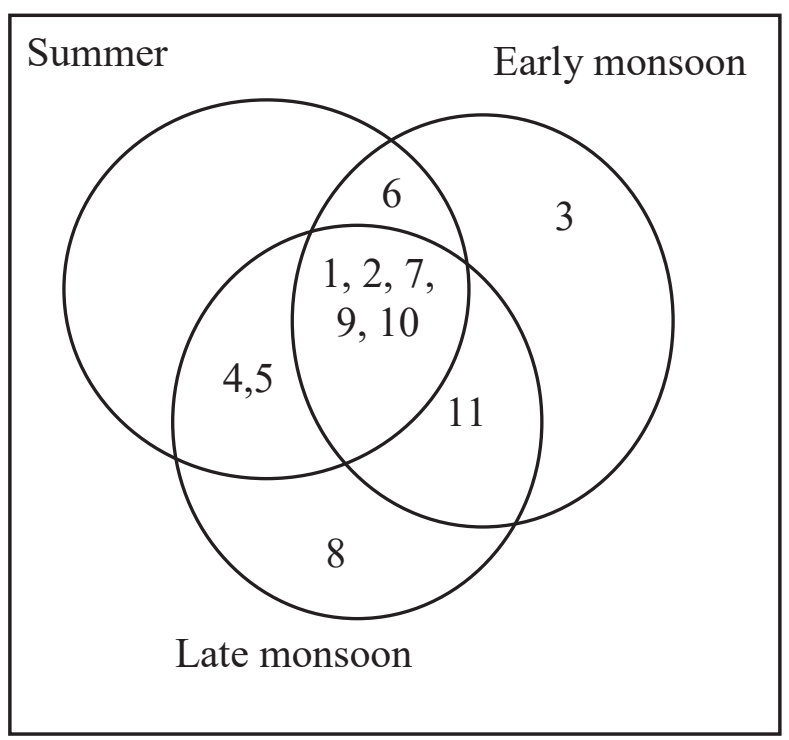

\begin{tabular}{|l|l|}
\multicolumn{2}{c}{ Index: } \\
\hline C.N. & Zooplankton \\
\hline 1. & Asplanchna sp. \\
\hline 2. & Bosmina sp. \\
\hline 3. & Brachionus sp. \\
\hline 4. & Ceriodaphnia sp. \\
\hline 5. & Chydorus sp. \\
\hline 6. & Cyclops sp. \\
\hline 7. & Daphnia sp. \\
\hline 8. & Diaphanosoma sp. \\
\hline 9. & Diaptomus sp. \\
\hline 10. & Keratella sp. \\
\hline 11. & Moina sp. \\
\hline
\end{tabular}

Figure 6: Seasonal Distribution of Zooplankton genera in Khaste Lake

Baral (1996) reported large number of genera from chlorophyceae, bacillariophyceae and xanthophyceae from various lakes, rivers and streams including lakes of Pokhara valley, of which, most of them were plantonic algae. Bista et al. (2000) recorded the genera Cyclotella, Melosira and Synedra from bacillariophyceae and large number of genera from chlorophyceae and cyanophyceae 
throughout the year in Phewa Lake and Rupa Lake. Rai (2000) described the abundance of phytoplankton in lakes of Pokhara valley indicating the trends of eutrophication of lakes. Dhewajoo (2007) has reported the phytoplankton genera belonging to chlorophyceae, bacillariophyceae and euglenophyceae with the dominance of chlorophycean from Buduwa (Kamal Pokhari) in Pokhara, indicating the water body rich in nutrients. Rai and Bista (2001) found bacillariophyceae, chlorophyceae and cyanophyceae as dominant phytoplankton groups in Phewa and Begans lake where Cyclotella and Synedra were recorded in all seasons.

All these findings mentioned above clearly showed that, there was no sharp differences in seasonal distribution pattern in the planktonic diversity. Among the phytoplankton groups, members of chlorophyceae, bacillariophyceae and cyanophyceae were predominant in all season. Although some of them show little fluctuations in their appearance that may be due to some seasonal climatic and nutritional variations. Present study in Khaste Lake was found to be correlating with the findings of earlier investigations especially with reference to the lakes Phewa, Begnas and Rupa of Pokhara valley.

During the period of six months of investigation from April to September 2012 in Khaste Lake, it was found that from the point of view of diversity and seasonal distribution of phytoplankton, the chlorophyceae were dominant followed by bacillariophyceae and other classes. Among chlorophyceae Closterium, Desmidium, Krichneriella, Pediastrum and Scenedesmus and from bacillariophyceae, Cyclotella, Melosira, Navicula, Pinnularia, Synedra and Nitzschia were recorded in all seasons during study period.

Among the zooplankton, Sewell (1934) reported 15 species of cladocera, 10 species of copepoda, 10 species of rotifera and one species of ostracoda from the fresh water tank inside Indian museum compound. Chacko and Krishnamurthy (1954) recorded few species of cladocera and copepoda from there freshwater fish ponds in madras city, India. Nasar (1973) reported 16 species of rotifers from Bhagalpur, India. Pokharel (1995-96) reported 6 genera of cladocera, two of copepoda and three of rotifera in his studies in Balaju, Kathmandu: Dhewajoo (2007) reported 6 genera belonging to protozoa, rotifera, cladocera, ostracoda and copepoda from Buduwa (Kamal Pokhari) in Pokhara. Husen and Dhakal (2009) noted the fluctuations of plankton diversity in different season in Phewa lake.

The above findings favored in most of the aspect of the present study. It was found that some genera of zooplankton occurring throughout the study period while other showed their absence in certain season and reappeared later. Although most of the zooplankton species survive under a wide range of environmental conditions and their growth and density depends on number of physical, chemical and biological factors. The amount of food available to zooplankton is one of the vital factors along with other environmental conditions which control the zooplankton abundance and diversity in the lake (Swar and Fernando, 1980). The absences in regular records of some genera in this study supported the above fact

There is a significant relationship between growth of plankton and nutrients resulting from surface run-off water and sewage effluents from populated surrounding area of water bodies. The excessive growth of plankton clearly indicates the changing of aquatic habitat into eutrophication (Prescott, 1961). 


\section{ACKNOWLEDGEMENTS}

The authors are grateful to the research committee Prithvi Narayan Campus, for providing opportunity and fund for this research work. Likewise, we would like to express deep sense of gratitude to Mr. Kishor Kumar Pokharel, Associate Professor, Department of Zoology, for supervision and encouragement throughout this work.

\section{REFERENCES}

Baral, S.R (1996). Environment and Biodiversity in the context of South Asia, ECOS Nepal (Ecological society of Nepal)

Battish, S.K. (1992). Freshwater Zooplankton of India, Oxford and IBH publication, Pvt. Ltd. New Delhi.

Bista, J.D., R.P., Dhakal and T.B. Gurung (2001). Changing Environmental Status and their Impacts on flora and fauna of two major lakes (Fewa and Rupa) of mid hills region, Pokhara, Nepal, Annual Report NARC (fisheries), Pokhara (2001-2002). 19-26

Chacko, P.I and Krishnamurthy, B. (1954): Study on the plankton of three freshwater Fish Ponds in Madras city, India, Indo-pacific Fish council. (UNESCO). 103-107

Dhewajoo, R.G. (2007). Limnobiotic studies of Buduwa (Kamal Pokhari), Abstract of National Seminar on sustainable use of Biological Resource ECOS. 50-51

Hensen, V. (1887). Ueber die bestimommung des Plankton oder des in Meere treibenlen Materials on Pflanzen and Theieren, Ber. Kommn wiss. Untress. dt. Meere, 5: 1-105

Majupuria, T.C. (1984-85). Nepal Nature's Paradise, White Lotus Company Ltd. Bankok, Thailand.

Panta, R. (2008). Wetland Management and Sustainable Livelihood in Pokhara Valley, Nepal, Kathmandu, National Lake Conservation Development Committee
(NLCDC).

Pennak, R.W. (1953). Fresh Water Invertebrates of the United States. The Ronald Press Company New York, U.S.A.

Prescott, G.W. (1961). Algae of the Western Great Lake Area; W.M.C. Brown Company Publisher, USA

Rai A.K. (2000). Limnological characteristics of subtropical lakes Phewa, Begnas and Rupa Pokhara Valley, Nepal. Limnology. 1:33-46

Rai, A.K. and J.D. Bista (2001): Review on Limnological studies of sub-tropical Lakes Phewa, Begnas and Rupa of Pokhara Valley and Indrasarobar Reservoir of Kulekhani, Nepal. Annual Report (2001-2002) NARC Pokhara, Kaski. 29-36

Sewell, R.B.S. (1934). Studies on the bionomies of freshwater in India, on the fauna of the tank in the Indian museum compound and seasonal changes. Int. Rev. Ges. Hydrobiologia. 31-36

Sharma, B.K. and R.G. Michael (1980). Synopsis of taxonomic studies on Indian Rotatoria. Hydrobiologia.73: 229-236

Swar, D.B. and C.H., Fernando (1980). Some studies on the ecology of limnetic crustacean zooplankton in lakes Begnas and Rupa. Pokhara Valley, Nepal, Hydrobiologia. 70: 235-245 